\title{
Study on the Conflicts Resolving Method of International Agent Law
}

\author{
Bin $\mathrm{Ma}^{1}$ \\ Xi'an International University, 710077 \\ hunter2011@foxmail.com
}

Keywords: Conflicts; Resolve Method; International Agent Law

\begin{abstract}
Legal conflicts agency system puts forward "new issues" for international private law. This has been developed simultaneously in various countries about conflict rules, and many countries strive to contribute to a number of international organizations related to international treaties. Referred to "agency legal application of the convention" and compared the provisions of "Rome Convention", this article will study application of international law and explore and research agency.
\end{abstract}

\section{Introduction}

International agency is a kind of international factor, or from the perspective of a particular country, the agency relationship has foreign elements. These foreign elements include: an agent or himself or a third person has a different nationality or domicile in different countries; in my capacity as an agent with a third person established foreign-related civil relations: the agent according to my commission agent himself in another country or implementation of agent behavior areas. From the agent's perspective, the general basic situations can occur there are several international agency: (a) a person in a foreign country as their proxy agent behavior; (b) an agent of foreigners in their own country for the legal act; (c) Chinese people a second agent in a third country for the legal act; (d) a foreign agent in a foreign country for the legal act. However, since all of the above cases, the third party may be any one of the people, therefore, the situation will be more complicated. Our analysis here is that at least one foreign elements of the case, once with a foreign element, it can be called a foreign agent. At this time no amount of foreign elements added to the amount of change only, and will be more to strengthen its foreign properties.

Any legal system must reflect the specific needs of the community, and to respond to this social demand is the system value lies. It is that the legal system to produce and causes exist. With the continuous development of commodity economy, the increasing size of the transaction, "profit maximization" objective will encourage business people to invest in a wider field of vision and geographical, of course, the problem appears: First of all, due to the increased volume of business, businessman sometimes feel "spare no surgery" because the time and energy, after all, is limited; secondly, in the process of opening new markets, shrewd businessman found that the use of local resources can often achieve a "multiplier" effect. Thus, the agency system have come into being.

\section{Conflict of Laws about International Agency System}

General Theory of Conflict of Laws. In private international law, conflict of laws refers to the conflict of laws applicable to the same foreign-related civil legal relationship, because different countries involved in civil law occurred on. Produce legal conflict is the result of joint action by the following reasons: National civil law system are different. Here's civil legal system, including commercial legal system. Since the social system of the world, economic development and historical and cultural traditions are different, their legal systems vary widely. In the civil legal system, this difference is particularly prominent. There is a normal civil exchange between countries, forming a large number of international civil relations. The emergence and development of private international law is civil status changes and foreigners, and to improve the country's closely related factor, many scholars believe that, given the legal status of foreigners is an important condition for the civil international civil exchanges can proceed. Any law has a certain validity 
range, some only within potency, effectiveness both within and some have extraterritorial effect. In general, countries recognize the extraterritorial effect of foreign civil law under certain conditions, it is precisely because of the mutual recognition of each country, it produced a civil legal conflict.

The Performance of the International Agency Conflict of Laws. Civil law countries according to different standards of agents have the following classification: 1, direct and indirect proxy agent. It is divided into whether agents "in my name" and the third party agent behavior made under. Direct proxy is a proxy within his rights to make the agent acts in my name and I assume the legal effect: indirect proxy refers to an agent in its own name, as it made my calculation agent behavior, their legal effect and then transferred in himself the agent. The positive and negative proxy agent exists there. Active agent is an initiative to make sense based on the agent or passive acceptance of intention to make a division in active agent, the agent who is made outside of intention, in contrast negative agent, the agent is a passive acceptance of intention. We have no right to act on the agent. It is divided according to whether the agent-based agency and the agent behavior made. Authorized agency refers to the right to the agent-based agent; unauthorized agency refers to his agent does not proxy. Unauthorized agency can be divided into narrow unauthorized agency and agency by estoppel both cases, the so-called narrow unauthorized agency simply refers to an agent without my authorization, but also no reason to trust the third person and as my proxy; Table See the proxy is a proxy Although there is no right, but the third person has reason to believe that the agent can be trusted is a "power of attorney", on the basis of the transaction with the agent and agent configuration. Although it is an unauthorized agency by estoppel, countries have the right to produce many of the prescribed proxy same effect that the legal consequences to be borne by himself. Generally refers to the scope of the proxy and power of attorney is not particularly restricted, and Special Agent means the agent has special privileges restricted agents.

\section{The Method of Direct Adjustment of an International Harmonization of Substantive Law Agents}

By way of harmonization of substantive law to resolve legal conflict began in late 19th and early 20th century, with the international civil and commercial relations increasingly developed, the traditional conflict rules governing international private law gradually exposed the inherent flaws, because the legal relationship conflict rules The adjustment is an indirect adjustment, lack of clarity, predictability and targeted, while in the process of conflict rules applicable, there is inevitably a series of legal issues, such as recognition, turn cause, public order reservations and so on, very a large reduction in the effectiveness and efficiency of conflict rules, damage to the parties to resolve the conflict of laws applicable conflict rules enthusiasm. This unified substantive law is the most common form of international treaties. To date, through the joint efforts of the international community in the field of sale of goods, transportation, insurance and trade payments and intellectual property, a number of international treaties began to play an important role, such as 1883's "Paris Convention for the Protection of Industrial Property," 1980's". The United Nations Convention on Contracts for International Sale of Goods. "

Facilitate the achievement of substantive law convention on international agents, so that in practice it is difficult to solve the problem and reduce to a minimum, it has been the ideal target countries jurist and business people are pursued, the International Institute for the Unification of Private Law in this regard has played a big role. The association drafted a series of conventions, namely in 1961, "agent uniform regulations", "commission contract unified regulations," 1967 "Transport agents Convention," 1983 "international cargo sales agents of the Convention," 1988 "international protection Acting pay Convention ", the ILA draft convention also proposed two related agency in 1950 and 1952, the draft and the draft Lu Sesi Copenhagen. Also in 1986, the EC Council adopted the "law on inter-agency coordination of the Member States relating to the instruction," the law of agency to promote regional unity made outstanding contributions more realistic.

In the above-mentioned international conventions related to the agent, the "Convention on the International Sale of Goods agents' representative significance, not only because of his broader 
scope compared with previous conventions, generally, but also because the process of the development of the convention and help in our understanding of violent conflict in the proxy law countries. As early as 1935 UNIDROIT proceeded to work the unified agent law. After many changes until 1972, party to work out a unified text of the draft regulation periods. The text excludes certain types of agents is limited to adjust the sales agent of international cargo, which aims to adjust both the effectiveness of international cargo relations agent's actions; they regulate the internal relationship between himself and the agents, while abandoned the mainland Law direct and indirect proxy agent distinction. However, the draft in 1979, held in Bucharest on Foreign Affairs meeting _ not been adopted, in 1980, the International Institute for the Unification of Private Law held its 59th session, decided to organize a three experts including common law, civil law and socialist legal system consisting of Group of the existing text comprehensive review and revision. On the basis of the group through extensive and in-depth research, we agreed that: because the basic

method of proxy between different legal systems have considerable differences in terms of international law of agency, for the agency contract and intermediaries have different classification, therefore, to develop a range extensive and comprehensive uniform legislation is very difficult. The group proposes to abolish the draft text in Chapter 3, namely delete controversial about the relationship between the agent and the 1 section, only for external relations to develop a unified regulatory agency. In 1981, government-level committee of experts held in Rome in three teams submitted a proposal to re-develop the new text. February 1983 clever text of the resolution adopted last May, known as the "Convention on the International Sale of Goods agents." The Convention has not yet entered into force.

\section{Conclusion}

From the point of view of private international law, the "Convention on the Law Applicable agent" created an international agency and issued a practical system of conflict rules, largely reconcile the different civil law and common law in the application of the law on agent regulations and differences, "agency legal application of the convention" is important for Attorneys law applicable legislation and judicial practice, although the Convention itself there are still some deficiencies and shortcomings. Unified substantive law is the inevitable trend of development of private international law norms, in terms of the international agency. Unified entity specification will finally replace the conflict rules. States on the proxy differences and debate, not irreconcilable, now is the time and effort required. Principle of freedom of contract allows us to use a new method to resolve the conflict of laws, sign a comprehensive contract and it is a more realistic approach. In a word, compromise approach may not be the best, but it is effective.

\section{References}

[1] Shuan Y: China and The Unidroit Process (Revised Edition), Wuhan University Press, January 1998 Edition ..

[2] Morris Editor: "Daisy and Morris on the Conflict of Laws", Shuang Yuan Such As Translation, China Encyclopedia Publishing House, 1998 Edition.

[3] Zheng-Zi W: "International Research Agency Law", Law Press, October 1998.

[4] Xu-Dong G. "International Conventions and Practices" (International Private Volumes) Legal Publishing House, 1998.

[5] Shao-Jing C: International Contract Law Theory, Peking University Press, 1997 Edition. 